\title{
POTENTIAL OF AGRICULTURAL LAND MANAGEMENT ACTIVITIES FOR INCREASED SOIL CARBON SEQUESTRATION IN AFRICA- A REVIEW
}

\author{
OLADIMEJI OLADELE ${ }^{1 *}$, AND ADEMOLA BRAIMOH ${ }^{2}$ \\ ${ }^{I}$ Department of Agricultural Economics and Extension, North-West University, Mafikeng \\ Campus, Private Bag X2046 South Africa \\ (phone:+27-18-389-2746; fax +27-18-389-2748) \\ ${ }^{2}$ Agricultural and Rural Development, The World Bank, 1818 H Street, NW, Washington DC \\ 20433 USA \\ abraimoh@worldbank.org \\ *Corresponding author \\ e-mail: oladele20002001@yahoo.com \\ (Received $26^{\text {th }}$ Nov 2012; accepted $22^{\text {nd }}$ July 2014)
}

\begin{abstract}
This paper reviewed the potential for agricultural land management activities for increased soil carbon sequestration with particular reference to Africa. The sections of this review covered different land management activities (including agroforestry, conservation tillage, fallow management, mulching/cover crops, water management, rotation, manure, fertilizer use, grazing management) which lead to carbon sequestration in different farming systems. This review has revealed that there is high potential to sequester additional carbon through selected land management practices. The performance of these practices depends on soil properties and climatic conditions, and the degree of soil degradation at the time of time of intervention. There is need to integrate these land management practices for carbon sequestration into larger sustainable development and livelihoods strategies and practices in order to enhance an holistic approach and reduce some of the constraints that may inhibit these positive effect of land management practices for carbon sequestration.
\end{abstract}

Keywords : climate change, land management, soil carbon, conservation

\section{Introduction}

Africa, the second largest continent, has a wide diversity of climates, ecosystems and soil conditions. Since the 1960s, the continent has been experiencing serious economic and environmental problems. The growth of its population, the highest in the world, has placed pressure on many ecosystems. In addition, there has been political and social turmoil in many countries. Farming systems in Africa have been evolving towards landuse intensification in response to population growth and the scarcity of land suitable for long-fallow shifting cultivation. In many agro(eco)systems the soil has been degraded, due mainly to deforestation, overgrazing, agricultural mismanagement, and over exploitation. These degraded systems can be managed to reduce carbon emissions and increase carbon sinks in vegetation and soil (Table 1), thus contributing to global climate change mitigation (WBBGU, 1998).

The Green House Gas (GHG) mitigation potential of Sustainable Land Management (SLM) in agricultural lands is very large (Liniger, et al 2011). SLM strategies and practices can prevent land degradation, restore degraded lands, and reduce the need for further conversion of natural forests and grasslands. Farmers can, reduce GHG emissions, increase carbon sequestration, and maintain above- and below-ground carbon stocks at relatively low cost, while also improving food production and livelihoods.

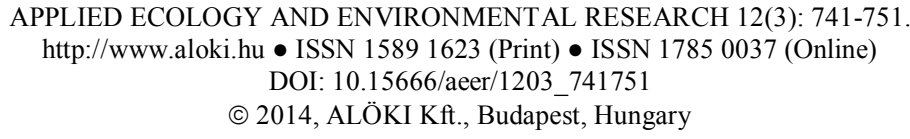


Improved agricultural practices can reduce carbon emissions from soil erosion and disturbance, and capture carbon from the atmosphere to store long-term in soils. Practices like cover cropping, applying crop residues, mulch, manuring, reduced tillage, and rotational cropping with legumes increase organic matter in soil, while also increasing crop yields. With better agronomic practices, nutrient and water management, reduced tillage and crop residue management, African croplands could potentially reduce GHG emissions by 2.0-3.5 million tons of $\mathrm{CO}_{2}$ eq per hectare per year or a total of 52.3-91.5 million tons of $\mathrm{CO}_{2}$ eq equal to 5-9\% of annual African fossil fuel emissions in 2005 (Liniger, et al 2011). As part of SLM, farmers grow trees in and around their farm fields, to harvest useful products such as fruit, livestock fodder and medicines. This benefits the climate as well as ecosystems. In humid zones of Africa, retaining shade and understory trees in cacao can provide vast carbon stores. For example, mature cacao agroforestry systems in Cameroon store 565 tons of $\mathrm{CO}_{2}$ eq per hectare. Even in semi-arid lands, agroforestry systems like intercropping or silvopasture, with 50 trees per hectare, can store 110 to 147 tons of $\mathrm{CO}_{2}$ eq per hectare in the soil alone (Liniger, et al 2011).

Table 1. Average stock and density of soil organic carbon for the world, Africa and West Africa (in first $1 \mathrm{~m}$ of soil)

\begin{tabular}{|l|l|l|l|}
\hline Soil organic carbon & World & Africa & West Africa \\
\hline Soc stocks $(\mathrm{Pg} \mathrm{C})$ & $1462-1548$ & $170-180$ & $25-27$ \\
\hline SOC density $\left(\mathrm{kg} \mathrm{C} \mathrm{m}^{-2}\right)$ & $10.9-11.6$ & $6.4-6.7$ & $4.2-4.5$ \\
\hline
\end{tabular}

Source: Batjes, 1996

Sanchez (2000) reported the carbon uptake rates, time average carbon stocks and differences in carbon stocks from land transformation at margins of the humid tropics. Similarly specific agricultural management and land-use options are available for $\mathrm{C}$ sequestration in tropical and subtropical soils. These include conservation tillage (notill/minimum-till) in combination with planting of cover crops, green manure and hedgerows; organic residue management mulch farming, particularly in dry areas; water management, including in-situ water conservation in the root-zone, irrigation, and drainage to avoid potential risk of salinization and water-logging and soil fertility management, including use of chemical fertilizers and organic wastes, rhizobium inoculation, liming and acidity management in order to take advantage of the $\mathrm{CO}_{2}$ fertilization effect. Others are introduction of agroecologically and physiologically adapted crop/plant species, including agroforestry; adapting crop rotations and cropping/farming systems, with avoidance of bare fallow; controlling of grazing to sustainable levels and stabilizing slopes and terraces.

The following sections consider these land use practices in details, documenting the GHG mitigation potentials as reported in scientific journals and reports.

\section{Nutrient management}

Nutrient management aims at managing soil by combining different methods of soil fertility amendment together with soil and water conservation. It takes into account all farm resources and is based on 3 principles: (1) maximizing the use of organic sources of fertilizer; (2) minimizing the loss of nutrients; (3) judiciously using inorganic 
fertilizer according to needs and economic availability. In Sub-Saharan Africa, soil fertility depletion is reaching a critical level, especially under small-scale land use. These techniques can rehabilitate degraded soils and then maintain soil fertility by using available nutrient resources in an efficient and sustainable way. Given the high cost of inorganic fertilizer, however, micro-fertilization has been a cost-saving entry point. The nutrient management practices considered in this review were the use of chemical fertilizer and animal manure.

\section{Chemical fertilizer}

There were several studies on the use of fertilizer in Africa, and the impact on soil nutrient particularly soil carbon. Snapp et al, (1999) stated that recommendations for fertilizer use on cereals in Malawi and Zimbabwe are in the range of 40-90 kg N per ha -- approximately ten-fold the amount of current fertilizer use by smallholders. Fertilizer use rates in Africa are only $8 \mathrm{~kg}$ ha- 1 with most of fertilizer applied to cash crops for export (Buerkert et al., 2000; Morris et al., 2007), while FAO, (2005) indicated that only fourteen percent of the total land area of South Africa receives sufficient application rates of 46 to $92 \mathrm{~kg}$ P2O5/ha for decreasing soil P- levels. Similarly, Minot (2009) stated that the overall, fertilizer application rates in Africa is $10-12 \mathrm{~kg}$ of nutrients per hectare.

The impact of fertilizer application cannot be widespread due to the fact that fertilizer is often not available for farmers in SSA and when available, it is not timely for farm operations and usually very expensive. For all the different treatments covered in this review, the mean impact of the fertilizer application was $626 \mathrm{~kg} \mathrm{C} \mathrm{ha}^{-1} \mathrm{yr}^{-1}$. Many of the studies focused on different levels of Nitrogen and the combination of fertilizer with locally available manure sources.

According to ICRISAT, (2009), micro-fertilization and microdosing involve the application of small, affordable quantities of fertilizer onto the seed at planting time, or a few weeks after emergence. The microdosing technique increases the efficiency of fertilizer use, and helps improve productivity. The method uses about one-tenth of the amount typically used on wheat, and one-twentieth of the amount used on corn in the US. The small dosage needed illustrates just how depleted of nutrients African crops are. The microdosing method has been introduced to Zimbabwe, Mozambique and South Africa, making fertilizer use a productive and economically viable option for the farmers. Abdoulaye and Sanders (2006) reported that many Nigerian farmers have been using micro-fertilization such that small quantities of inorganic fertilizer (compound fertilizer of NPK: nitrogen $15 \%$, phosphorous $15 \%$, potassium $15 \%$ ) up to $25 \mathrm{~kg} / \mathrm{ha}$ are put in the planting hole along with manure and the seed. Farmers repeatedly point out that the micro-fertilization increases the vigor of the seedlings and therefore there is less replanting required. Moreover, there is now substantial empirical evidence for the significance of the yield gains from micro-fertilization and their profitability from widespread trials over two years (2002 and 2003, an adverse and a good rainfall year) in Niger, Mali, and Burkina Faso (Tabo et al., 2005,).

\section{Animal manure}

Closely related to the issues of fertilizer experiment and trials was the use of animal manures. Most of the experiment conducted across the ecological zones shows that animal manure increased soil carbon tremendously. This might have been popular due 
to the prevailing farming system in many countries in Africa where livestock production is integrated with field crops.

Manure application to agricultural soils can reduce net GHG emissions in two ways. First, by the displacement of more typical anaerobic storage options with aerobic decomposition of organic material, $\mathrm{CH}_{4}$ emissions can be reduced. Second, soil application can sequester soil $\mathrm{C}$ and displace $\mathrm{N}$ fertilizer use, also potentially reducing field $\mathrm{N}_{2} \mathrm{O}$ emissions. Some of these benefits have already been recognized in efforts to divert organic waste from landfills. The impact of composting on emissions post-landapplication is of further interest. Fronning et al. (2008) examined GHG fluxes following land application of solid beef manure and composted dairy manure over a three-year period. Net $\mathrm{CH}_{4}$ flux was minimal $\left(<0.01 \mathrm{t} \mathrm{CO}_{2} \mathrm{e} \mathrm{ha}^{-1} \mathrm{yr}^{-1}\right)$, whereas untreated manure application generated higher $\mathrm{N}_{2} \mathrm{O}$ emissions than did compost $\left(0.9\right.$ versus $0.7 \mathrm{t} \mathrm{CO}_{2} \mathrm{e} \mathrm{ha}^{-}$ ${ }^{1} \mathrm{yr}^{-1}$ ). However, these land emission impacts were small when compared to soil $\mathrm{C}$ sequestration rates, which were 1.8 times greater for compost than for manure, suggesting that the organic matter stabilization during the compost process reduces post-application respiration losses. The net sequestration of $\mathrm{C}$ in the manure that is used for compost feedstock versus direct land application difference may also be affected by respiration losses during the composting process.

\section{No/Minimum Tillage}

There are varying degrees of carbon sequestered due to the levels of tillage reduction, it is a general trend that no tillage and reduced tillage increased carbon stocks in African soils; this particularly true for experiments conducted in the humid and forest regions. The main principle of conservation agriculture (CA) is minimal soil disturbance through reduced or no tillage. This favors soil life, and builds up of soil organic matter (less exposure to oxygen and thus less soil organic matter mineralization). Compared to conventional tillage, CA increases the organic matter content of soils, increasing their porosity and hence improving their ability to absorb and retain water. This has two positive effects: first, there is more water to support crop growth and the biological activity that is so important for productivity, and second, less water accumulates and thus doesn't flow across the surface, causing floods and erosion. Liniger et al (2011) noted that the potential for C Sequestration (tonnes/ha/year) in East Africa is $0.57 \pm 0.14$. Under 'minimum tillage and direct planting', land is prepared by slashing the existing vegetation and allowing regrowth up to $30 \mathrm{~cm}$ height. Herbicide is sprayed with a knapsack fitted with a low-volume nozzle. The residue is left on the soil surface without burning. After 7-10 days, direct planting is carried out in rows through the mulch. The mulch layer helps to increase and maintain water stored in the soil, reduces soil erosion, helps to improve soil fertility (after crop residues have decomposed in subsequent seasons) and it efficiently controls weeds by hindering their growth and preventing weeds from producing seeds.

\section{Residues}

These residues ranged from slaughter wastes to household wastes as well as crop residues. Composting is an important organic practice and a very important tool for adaptation to climate change. Composting involves the accumulation and proper mixing of animal manure, crop residues, weeds and organic household waste so that they can be

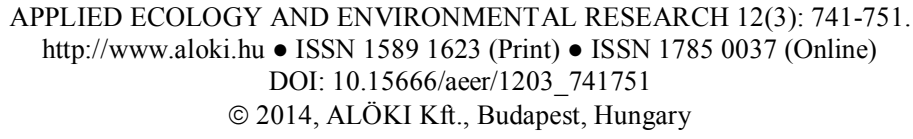


broken down into compost, which is used as a soil conditioner. During the composting processes fungi and bacteria decompose the raw material so that nutrients are stabilized within the organic matter. It also kills or reduces weed seeds, pests and diseases. Composting increases soil fertility by holding and gradually releasing nutrients and building up organic matter levels in the soil. Composting also improves the water holding capacity of the soil and makes crops better able to survive droughts and floods.

\section{Mulches}

The practice of mulching is naturally associated with the cultivation of some crops as it helps reduce loss of soil moisture; however the deliberate use of mulches and dry materials is usually considered a labor-intensive exercise. Most of the food crops that share the characteristics of cover crops were used for dual-purpose in Africa. Traditionally, these crops feature in the farming system and cropping pattern of most farmers. Some of the species used for cover crops as reported in the studies reviewed were Calliandra, Tithonia, Tephrosia, Chamacrista rotundifolia, Pueraria phaseoloides, Aeschynomene histrix, Centrosema pascuorum, Crotolaria ochroleuca, Mucuna deeringiana, M. pruriens, M. eracruz, Stylosanthes capitata and C.brasilianum.

\section{Agroforestry}

In Africa, of all agricultural land management activities suggested for GHG mitigation, agroforestry practices has been the most widely applied and studied, with the majority of research. Agroforestry has the potential to sequester significant amounts of carbon for 2 reasons. First, the area currently in crops and pastoral systems is large. Second, although the density of carbon storage is low in comparison with forests, the woody biomass of agroforestry systems could provide a source of local fuel. This fuel would reduce pressure on the remaining forests in the area and, at the same time, provide a substitute for fossil fuel. These effects are important because the most effective way to use land for stabilization of atmospheric carbon is not through reforestation but through the substitution of wood fuel for fossil fuel. Takimoto et al 2008 reported that Faidherbia albida parklands stored more C than improved agroforestry systems (live fence and fodder bank) or abandoned land. Similarly carbon sequestration potential of agroforestry systems varies greatly from under $100 \mathrm{Mt}$ to over 2000Mt of carbon dioxide equivalent per year particularly the use of Faidherbia albida, in Malawi and Niger.

Forests would continue to hold the carbon accumulated, but they would accumulate no additional carbon after that time. In contrast to the temporary effect of reforestation, the sustainable use of wood fuels provides a solution that could last indefinite. The biophysical and spatial potential for carbon sequestration in Africa is high; the sociopolitical conditions related to land usage, ownership and permited land management practices are not, constituting a serious dilemma for carbon storage on the continentand a similar dilemma for biofuel projects. The primary problem within this dilemma is land tenure, and no clear way ahead exists, despite the well-intentioned recommendations in the afforestation and reforestation carbon sequestration literature for the development and implementation of Western notions of property rights, along with improved governance, local participation, and sustainable development 
(KauppiandSedjo, 2001; Brown, 2002; Smith, 2002). Land tenure will be the most fundamental issue regarding how trees are to interact with African landscapes.

\section{Intercropping and Alley farming}

The practice of growing crops or pasture between rows of trees (alley farming) sequestered soil carbon. Beedy et al (2010) indicates that the use of the gliricidia intercrop had proportionately greater positive effects on rebuilding of soil fertility capital than on carbon sequestration, though both results are modest compared to impacts on maize yields over the course of 14 years in a semi-arid tropical maize cropping system in southern Africa. Particulate organic matter pools, which act as a reservoir of crop nutrients, were enhanced by the gliricidia/maize intercrop.

\section{Tree-crop farming}

Tree crops such as cocoa plantation in Ghana and Cameroon, Coffee plantation in Burkina Faso, indigenous fruit trees in South Africa, oil palm plantation in Cote d'Ivoire, exotic tree species in Ethiopia, rubber plantation in Nigeria and Ghana, Cashew and Teak plantation in Nigeria were covered. Ofori-frimpong et al (2010) noted that Cocoa planted at low plant density and under shade stores more carbon per unit area of soil than an equivalent area of cocoa planted at high density without shade. In addition to $\mathrm{C}$ sequestration in biomass and soil, tropical plantations are needed for timber, and more importantly, as fuel wood for cooking. Thus, the area under tropical plantations has increased drastically since the 1960s, from 7 Mha in 1965 to 21 Mha in 1980, 43 Mha in 1990 (Evans, 1986) and 187 Mha in 2000 (FAO, 2003). In Western Nigeria, Ekanade et al. (1991) reported that the SOC pool under forest was $29 \mathrm{~g} / \mathrm{kg}$ and that under cocoa was $19 \mathrm{~g} / \mathrm{kg}$. Similar observations were made by Adejuwon and Ekanade (1988) in Oyo state, Nigeria. Also in southern Nigeria, Ogunkunle and Eghaghara (1992) observed that the SOC concentration under 10-year old cocoa plantation was $25 \mathrm{~g} / \mathrm{kg}$ compared with $35 \mathrm{~g} / \mathrm{kg}$ under forest. In Nigeria, Aweto (1987) reported that the SOC concentration was $14 \mathrm{~g} / \mathrm{kg}$ under primary forest and $12 \mathrm{~g} / \mathrm{kg}$ under a 18-year old rubber plantation. The SOC concentration under rubber increased over time. In Kade, Ghana, Duah- Yentumi et al. (1998) reported that the SOC concentration of a soil under 40-year old rubber plantation was lower than that under virgin forest or 20-year old cocoa. Both rubber and cocoa received no fertilizer or manure.

\section{Land-use changes}

The impact of land-use changes on carbon sequestration has also been documented in the literature. Liniger et al (2011) reported that afforestation has high potential for $\mathrm{C}$ sequestration at a rate comparable to the use of conservation agriculture of no and minimum tillage. In this review, land-use changes focused on afforestation practices, grazing and cropping intensity. Lal (2004) noted that afforestation, the establishment of tree plantations has a large potential for SOC sequestration in the tropics. SOC accumulation under 18-year plantation of Acacia senegal in northern Senegal at the rate of $0.03 \% / y r$ under the tree canopy and $0.02 \% / y r$ in the open ground, corresponding to SOC sequestration rates of 420 and $280 \mathrm{~kg} \mathrm{C} / \mathrm{ha} / \mathrm{yr}$ for a soil bulk density of $1.4 \mathrm{Mg} / \mathrm{m} 3$.

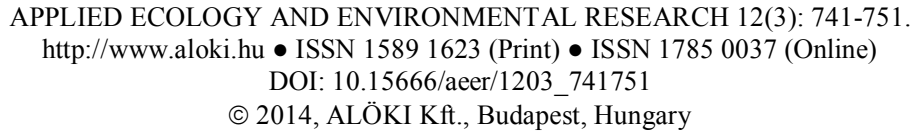


They also estimated, at a very general level, a potential sequestration capacity of 45.7 $\mathrm{Tg} \mathrm{C}$ per year through cessation of overgrazing, although research also has found that some grasslands sequester more carbon in response to heavier grazing intensities. Reeder and Schuman (2002) reported higher soil C levels in grazed - compared to ungrazed - pastures, and noted that when animals were excluded, carbon tended to be immobilized in above-ground litter and annuals that lacked deep roots. After reviewing 34 studies of grazed and ungrazed sites (livestock exclusion) around the world, Quattara et al (2006) reported that the average carbon stock in continuous cultivation system was $10.05 \mathrm{Mg}$ ha- ${ }^{1}$ in Burkina Faso.

\section{Soil Management}

The arrangement of crops in time and space is a common practice among farmers in Africa that allows for crop rotation and mixed cropping practices as dictated by their taste preferences and culture.

Crop rotation is the practice of growing a series of dissimilar types of crops in the same area in sequential seasons for various benefits such as to avoid the build- up of pathogens and pests that often occurs when one species is continuously cropped (Pearson et al, 1995). Crop rotation also seeks to balance the fertility demands of various crops to avoid excessive depletion of soil nutrients. A traditional element of crop rotation is the replenishment of nitrogen through the use of green manure in sequence with cereals and other crops. It is one component of polyculture. Crop rotation can also improve soil structure and fertility by alternating deep-rooted and shallowrooted plants. The sequence is usually cereal, cover crop/leguminous crop, tuber crops and cereals such maize, cowpea, cassava and maize. Pearson et al (1995) indicated that crop rotation pattern in West- African Sahel usually include Millet/sorghum, maize, groundnuts, cowpea, sesame, cassava, yams, tree legumes; while in Ethiopia the sequence follows Maize/barley, sorghum, millet, and tef.

\section{Natural and Improved fallow}

Fallow periods during which there is no crop on the land, can be reduced or managed to increase soil C stocks, especially if fallow coincides with conditions that could permit some vegetative growth (primary productivity). Depending on the region and cropping system, both the elimination of summer fallow and the use of winter cover crops have significant GHG mitigation potential. Ganry et al (2001) have shown that to ensure soil fertility management, a range of practices can be envisaged, such as spontaneous long fallow and cultivated parkland, improved herbaceous and bush fallows, cover-crop legume system, alley cropping system, compost and manure. Kotto-same (1997) reported that where bush fallow was well-established two years after land abandonment, dominated by Chromolaena odorata. The tree fallows consisted of dense understorey and nearly closed canopy of pioneer tree species. The most common tree species were Albizia zygia, Ficus exasperata and Myrianthus arboreus with understoreys of Aframomum longiscarpum and Haumania danckelmaniana. C. odorata in the tree fallows. 


\section{Water management}

Water management practices covered in this review were rain water harvesting, slope/barriers and terracing.

\section{Rainwater harvesting}

This practice is particularly important to framers in the semi-arid and arid region where there were few days of rains but rain -fed agriculture is practiced. Rainwater Harvesting (RWH) refers to all technologies where rainwater is collected to make it available for agricultural production or domestic purposes. RWH aims to minimize effects of seasonal variations in water availability due to droughts and dry periods and to enhance the reliability of agricultural production. A RWH system usually consists of three components: (1) a catchment / collection area which produces runoff because the surface is impermeable or infiltration is low; (2) a conveyance system through which the runoff is directed e.g. by bunds, ditches, channels (though not always necessary); (3) a storage system (target area) where water is accumulated or held for use - in the soil, in pits, ponds, tanks or dams. When water is stored in the soil - and used for plant production there - RWH often needs additional measures to increase infiltration in this zone, and to reduce evaporation loss, for example by mulching. Furthermore soil fertility needs to be improved by composting / manuring, or micro-dosing with inorganic fertilizers. Commonly used RWH techniques can be divided into micro-catchments collecting water within the field and macro-catchments collecting water from a larger catchment further away with potential for $\mathrm{C}$ sequestration (tonnes/ha/year) 0.26-0.46.

A Smallholder Irrigation Management (SIM) unit is typically a plot covering an area less than 0.5 ha. SIM schemes may be managed either by an individual land user or by groups / communities. The guiding principle of sustainable SIM is 'more crop per drop', in other words efficiency of water use. This can be achieved through more efficient (1) water collection and abstraction; (2) water storage; (3) distribution and; (4) water application in the field. Two main categories of SIM can be distinguished, traditional surface irrigation systems and recent micro-irrigation systems including drip irrigation. Micro-irrigation systems are commonly used for, and are very important in, the production of vegetables, fruits and flowers. Potential for $\mathrm{C}$ sequestration (tonnes/ha/year) is 0.15 (Liniger et al 2011).

\section{Cross slope barriers and terracing}

The practices of cross slope barriers and terracing sequester additional soil carbon . This is very critical in regions of high undulating surfaces and highlands. Cross-slope barriers are measures on sloping lands in the form of earth or soil bunds, stone lines, and / or vegetative strips for reducing runoff velocity and soil loss, thereby contributing to soil, water and nutrient conservation. This is achieved by reducing steepness and / or length of slope. Terraces are not usually constructed per se, but rather develop gradually behind earth bunds, vegetative strips (usually grass) or stone barriers, due to soil movement from the upper to the lower part of the terrace. Erosion between the barriers helps to achieve the leveling of the terrace bed. Potential for $\mathrm{C}$ Sequestration (tonnes/ha/year) 0.5-1.0 (Liniger et al 2011)

Biochar

These covered the use of Biochar from different plant sources in Kenya, Ghana and Cameroon to improve soil. Biochar is charcoal made from organic material burned 
during conditions with low oxygen level (pyrolysis). Previous trials have showed that biochar can or will in small scale farming: $\square$ Add nutrients and improve uptake of applied fertilizers, Increase water holding capacity of the soil, Increase carbon concentration in the soil, Remain resident in the soil over a long period of time, Affect decomposition rates of organic compounds. Alvum-Toll et all 2011 noted that Due to the high stability the constituent carbon, biochar added to soil may act as a carbon sink and might be part of a solution to the global warming problem by reducing the concentrations of carbon dioxide (CO2) in the atmosphere. Besides acting as a carbon sequester, biochar has several beneficial effects on soil properties, such as increased water holding capacity, enhanced CEC, BS, as well as add nutrients and improve the plant uptake of nutrients (Lehmann \& Joseph, 2009). However, research on biochar's effect on soil CEC is not coherent. Novak et al. (2009) did not find a significant increase in CEC after biochar addition. Biochar affects soil fertility in many ways; it can add nutrients by itself or make them more available for plant uptake by enhance the decomposition of organic material- or, possibly, reduce decomposition rates of other organic material thereby increasing soil $\mathrm{C}$ concentration in the long run. Moreover, the large surface area results in increased CEC, which may prevent nutrient leaching and thus eutrophication (Lehmann \& Joseph, 2009). Lehmann et al. (2003) found a significant decrease in leaching of applied fertilizers after charcoal addition.

Apart from the beneficial effects of drawing $\mathrm{CO} 2$ from the atmosphere, bio-char applications to soil are also able to reduce the emissions of other greenhouse gases. Nitrous oxide emissions were reduced by up to 50\% when bio-char was applied to soybean and by $80 \%$ in grass stands. These low emissions may be explained by better aeration (less frequent occurrence of anaerobic conditions) and possibly by greater stabilization of $\mathrm{C}$. The lower nitrous oxide evolution may also be an effect of slower $\mathrm{N}$ cycling (possibly due to a higher $\mathrm{C} / \mathrm{N}$ ratio).

\section{Soil Amendment}

In this review the use of soil amendments such as of Cocoa husk, rice bran/mill spent grain, ash and saw dust were covered. The literature suggest the great potential for the addition of a suite of amendments containing organic and inorganic energy related byproducts to improve degraded land increase sequestration of $\mathrm{C}$, and utilize energy byproducts. However, the optimal strategy for rapid enhancement of $\mathrm{C}$ sequestration is not currently known. In areas limited by specific elements, these products can supply micronutrients Micronutrient amendment from coal fly ash with sewage sludge was applied to an acid boron deficient loamy soil in China with resulting higher yield for cucumber and corn than either the control treatment or a boron-containing fertilizer. Ash additions to an easily clodded clay loam soil increased bulk density and desirable aggregates and decreased the modulus of rupture. Fly ash has been shown to increase porosity, water holding capacity, $\mathrm{pH}$, conductivity, sulfate, carbonate, bicarbonate, chloride and metals, although the effect is reduced in high clay soils. While surface soil $\mathrm{P}$ and $\mathrm{Mn}$ were also important, soil depth appears to be a positive factor in establishing white pine on mine spoil 


\section{Conclusion}

This review has revealed that there is high potential to sequester additional carbon through selected land management practices. Prominent practices include use of animal manure, residues, improved fallow, tree inclusion on farm field and use of slope and cross barriers and natural fallow. The performance of these practices depends on soil properties and climatic conditions, and the degree of soil degradation at the time of time of intervention. There is need to integrate these land management practices for carbon sequestration into larger sustainable development and livelihoods strategies and practices in order to enhance an holistic approach and reduce some of the constraints that may inhibit these positive effect of land management practices for carbon sequestration.

\section{REFERENCES}

[1] Abdoulaye, T., sanders, J.H. (2006) New technologies, marketing strategies and public policy for traditional food crops: Millet in Niger. Agricultural systems 90, 272-292.

[2] Adejuwon, J.O., Ekanade, O.(1988). A comparison of soil properties under different

[3] land use types in a part of the Nigerian cocoa belt. Catena 15: 319-331.

[4] Alvum-Toll, K., Karlsson, T., Strom, H. (2011) Biochar as soil amendment- a comparison between plant materials for biochar production from three regions in Kenya. Swedish University of Agriculture Sciences. Department of Soil and Environment

[5] Aweto, A.O. (1987). Physical and nutrient status of soils under rubber (Heveabrasiliensis) of different ages in southwest Nigeria. Agric. Systems 23: 63-72.

[6] Batjes, N.H (2008). Mapping soil carbon stocks of Central Africa using SOTER. Geoderma 146, 58-65.

[7] Beedy,T.L., Snappb, S.S., Akinnifesia, F.K., Sileshi, G.W. (2010) Impact of Gliricidia sepium intercropping on soil organic matter fractions in a maize-based cropping system Agriculture, Ecosystems and Environment 138 (2010) 139-146

[8] Bowman D M J S. (2000). Tropical rain forests. Progress in Physical Geography 24(1): 103-109.

[9] Buerkert, A., Bationo. A., Dossa, K. (2000). Mechanisms of residue mulch induced cereal growth increases in West Africa. Soil Sci. Soc. Amer. J., 64: 346-358.

[10] Duah-Yentumi, S., Ronn, R., and Christensen, S. (1998), 'Nutrients limiting microbial growth in a tropical forest soil of Ghana under different management', Applied Soil Ecology, Vol 8, Nos 1-3, pp 19-24.

[11] Evans, J. (1986), 'Plantation forestry in the tropics - trends and prospects', The International Tree Crops Journal, Vol 4, pp 3-15.

[12] FAO. (2003). State of the World Forests. FAO, Rome, Italy.

[13] FAO, (2005) Fertilizer use by crop in South Africa. Food and Agriculture Organization of the United Nations Viale delle Terme di Caracalla 00100 Rome, Italy

[14] Ganry, F, Feller,C., Harmand J-M., Guibert, H. (2001) Management of soil organic matter in semiarid Africa for annual cropping systems Nutrient Cycling in Agroecosystems 61: 105-118, 2001.

[15] International Crops Research Institute for the Semi-arid Tropics(ICRISAT) (2009), Fertilizer Microdosing : Boosting production in unproductive land. ICRISAT. 1-3

[16] Lal R (2004) Carbon Sequestration in Dryland Ecosystems Environmental Management Vol. 33, No. 4, pp. 528-544

[17] Lehmann, J., Joseph. S. (2009). Biochar for environmental management. UK: Earthscan. p. $16,19,22,23,67,68,70,71,75,76,77,79,86,87,89,116,117,127,133,15853$ 
[18] Lehmann, J., Pereira da Silva Jr, J., Steiner, C., Nehls, T., Zech, W., Glaser, B. (2003). Nutrient availability and leaching in an archaeological Anthrosol and a Ferralsol of the Central Amazon basin: fertilizer, manure and charcoal amendments. Plant and Soil 249, 343-357.

[19] Liniger, H.P., R. Mekdaschi Studer, C. Hauert and M. Gurtner. (2011). Sustainable Land Management in Practice - Guidelines and Best Practices for Sub-Saharan Africa. TerrAfrica, World Overview of Conservation Approaches and Technologies (WOCAT) and Food and Agriculture Organization of the United Nations (FAO)

[20] Morris, M., Kelly V. A., Kopicki, R.J., Byerlee, D. (2007). Fertilizer Use in African Agriculture: Lessons Learned and Good Practice Guidelines. Washington DC: World Bank.

[21] Novak, J.M., Busscher, W.J., Laird, D.L., Ahmedna, M., Watts, D.W., Niandou, M.A.S. (2009).Impact of Biochar Amendment on Fertility of a Southeastern Coastal Plain Soil. Soil Science 174, 105-112.

[22] Ofori-Frimpong, K., Afrifa, A. A., Acquaye,S. (2010) Impact of shade and cocoa plant densities on soil organic carbon sequestration rates in a cocoa growing soil of Ghana African Journal of Environmental Science and Technology Vol. 4(9), 621-624,

[23] Ogunkunle, A. O., and Eghaghara, O. O. (1992), 'Influence of land use on soil properties in a forest region of Southern Nigeria', Soil Use and Management, Vol 8, No 3, pp 121125.

[24] Pearson, C.J., Norman, D.W., Dixon, J. (1995) Sustainable dryland cropping in relation to soil productivity - FAO soils bulletin 72 . Publications Division, Food and Agriculture Organization of the United Nations, Viale delle Terme di Caracalla, 00100 Rome, Italy.

[25] Quattara, B, Quattara, K., Sepantite, G., Mando, A, Sedogo, M.P., Bationo, A (2006) Intensity cultivation induced effects on soil organic carbon dynamic in the western cotton area of Burkina Faso. Nutr. Cycl. Agroecosyst. 76, 331-339

[26] Smith, C.W., Johnston, M.A., Lorentz, S., (1997) Assessing the compaction susceptibility of south African Forestry soils. I. The effects of soil type, water content and applied pressure on uni-axial compaction. Soil and Tillage Research 41, 53-73.

[27] Snapp, S. S, Phiri, R., Moyo, A. (1999) Soil Fertility Experimentation and Recommendations for Drought-prone Regions of Zimbabwe and Malawi, in Risk Management for Maize Farmers in Drought-Prone Areas of Southern Africa, CIMMYT, ICRISAT, Danida, Mexico, DF pp13-24

[28] Takimoto, A, Nair, P.K.R., Nair, V.D. (2008). Carbon stock and sequestration potential of traditional and improved agroforestry systems in the West African Sahel. Agriculture, Ecosystems \& Environment 125:159-166. 